\title{
Impact of enterprise information systems on selected business performance indicators in construction industry
}

\author{
Annamária Behúnová1, Tomáš Mandičák², Katarína Krajníková3 \\ Peter Mesároš ${ }^{4}$, Marcel Behún ${ }^{5}$, \\ \{annamaria.behunova@tuke.sk, tomas.mandicak@tuke.sk², katarina.krajnikova@tuke.sk ${ }^{3}$ \}
}

Technical University of Kosice, Department of Industrial Engineering and Informatics, Bayerova 1, Presov ${ }^{1}$, Technical university of Kosice, Faculty of Civil Engineering, Vysokoskolska 4, Kosice ${ }^{2,3}$

\begin{abstract}
Business performance depends on many factors. On the one hand, there are primarily people and their skills and competencies. Another important factors are methods and management system, but also devices, technology and information systems. The combination of new technology and management system can have a big impact on business performance. Implementation of new technology such as enterprise information system should be an asset for the enterprise. If it is assumed that enterprise information system positively perceives to business performance, it is necessary to quantify, or verify this claim. Measurement of financial indicators is not the only way of measuring corporate performance. Although it is for the proper management and receipt management decisions necessary to know these indicators. Research discusses issue of enterprise information system impact on business performance indicators in construction industry in Slovakia. Main objective of research was set as confirmation of hypotheses, that enterprise information system has impact on selected business performance indicators.
\end{abstract}

Keywords: enterprise information system, business performance indicators, construction industry.

\section{Introduction}

Successful enterprises in construction industry implement the latest technologies in the production process but also in management process. Progressive information technology makes it easier to collect and work with information [1]. Information is necessary in each area [2]. At present, the importance of information systems for enterprises is growing in ensuring their successful development in conditions of growing competition [3],[4]. The mission and tasks of enterprise information systems have changed significantly over the last decades [5]. Actually, enterprise information systems have become an essential part of corporate management [6]. These systems greatly support productivity, competitiveness of enterprises and acquire strategic importance as a factor creating competitive advantages [7]. The basic prerequisite for rapid deployment and especially efficient use of enterprise information systems is a proper understanding of their nature and function [4]. Enterprise information system is a set of the additional hardware and software networks that people and enterprises use to data collection, creation and distribution [8]. According to [9] Berisha-Namani, 
enterprise information systems support decision-making in organizations. The use of information systems to support decision-makers is one of two general categories of systems that help users analyse the situation and leave a decision on it [10]. Enterprise information systems are the carriers of a method of efficient planning and management of all corporate resources in any business, whether it is a manufacturing enterprise or a service enterprise [11]. The focus on the role of information systems in enterprise structures their impact on business performance by using information technology based on the practical application of IT, technical alignment, IS capabilities and IS effectiveness is to connect processes, people and technology for the purpose of maximizing corporate IT, technical alignment, IS capabilities, and IS effectiveness [12]. It is proposed to achieve the information integrity of the construction process and control system of information and resource flows of industrial divisions in construction industry [10]. Implementation and improvement of information systems infrastructure brings great expectations from users and management. The data are useless unless people know how to process them effectively [13]. Based on these authors and other studies, enterprise information systems brings many benefits [14]. However, corporate governance raises the question of how these technologies impact on the financial performance of enterprises.

From this perspective, it is therefore necessary to measure business performance. Business performance management (BPM) is an integrated set of methods, processes, metrics, and applications designed to manage the financial and operational performance of enterprise [15]. Business performance management includes target management, performance management, resource management and process interface management [16]. Based on previously research, performance management includes receiving regular feedback on the process outputs and monitoring the actual performance by measurement dimensions set in targets. Accounting measures of performance have been the traditional abutment of quantitative approaches to business performance measurement [17]. Implementing the performance implementation plan and monitoring enhanced progress leads to continuous business process performance enhancements [18]. It is necessary to define key performance indicators to monitor business performance and set goals. These are the most important performance indicators that reflect the organization's strategic objectives and measure the performance achieved in relation to these goals [19]. The complementary approaches that have been developed move away from a concertation on accounting measures alone, and add consideration of a wider range of factors which are believed to drive future economic performance [20]. According this study, business performance indicators are profitability, market share, productivity and other financial indicators. Other authors prefer financial indicators like cost, revenues and so on. Like any other organization, it has become essential for the organizations in the construction industry to measure their performance effectively for long-term survival in today's competitive business environment. Therefore, it is imperative for a construction organization to know about various performance measurement factors to evaluate its performance [21]. Performance measurement systems provide a mechanism to focus on wider business performance measures, which enables organisations to implement business improvement [22]. It also applies to the implementation of new technologies, such as enterprise information systems [23]. Increasing of information and communication technology impact on productivity levels and developing of managerial competencies of managers, too [24]. When implementing new technologies, it is very important to quantify the impact on performance [25]. Tracking costs is main step for profitability a quantifying of efficiency. Especially, total cost and sot on management processes. But what is the impact of implementing enterprise information systems on the costs of the construction enterprise? And 
what impact does enterprise information system have on the development of revenue and profit? These are very important issues to be examined.

\section{Methodology}

\subsection{Research aim and hypotheses}

Based on theoretical analysis it was set main research aim. It is to analyse and quantify the impact of enterprise information system on selected business performance indicators. Partial aims of research were answer to the basic of research questions:

- What is impact of enterprise information systems on business performance?

- What is impact of enterprise information systems on cost in construction enterprises?

- What is impact of enterprise information systems on revenues in construction enterprises?

Based on research questions were set research hypotheses:

\section{Hypotheses for research area - impact of enterprise information systems on cost in construction enterprises}

$\mathrm{H}_{0}$ : The mean ranks of two groups are equal.

$\mathrm{H}_{1}$ : The mean ranks of two groups are not equal (assume that mean of „,cost before enterprise information system implementing" > mean of cost after enterprise information system implementing ")

\section{Hypotheses for research area - impact of enterprise information systems on revenues in construction enterprises}

$\mathrm{H}_{0}$ : The mean ranks of two groups are equal.

$\mathrm{H}_{1}$ : The mean ranks of two groups are not equal (assume that mean of ,revenues after enterprise information system implementing" > mean of cost before revenues information system implementing ")

\subsection{Data collection and research sample}

All data in research were conducted by on-line form questionnaire. The research sample was approached by e-mail with the request to participate in the research to Slovak construction enterprises. Total were interviewed 1276 of respondents (construction enterprises in Slovakia). It participated in the questionnaire survey 111 respondents. It represents a return of $8.70 \%$. Generally, it is possible to return to the level of $8.70 \%$ is considered as good.

The structure of the questionnaire was as follows. First part of questionnaire, it was general information about respondents. Next part was important from research point of view. It was set questions about level of cost and revenues before and after enterprise information system implementing. To determine the answer was used "Likert scale ranging" from 1 to 5 on the basis of fixed values has been done the arithmetic average of the values for the selected 
area under consideration. 1 - is very low level of cost/revenues and 5 - is the very high level cost/revenues. The extent and interval values for each stage of the scale were thoroughly explained to the respondents.

Research sample included participants of construction projects. There were contractor enterprises, investors and developers and designers. Research sample from size and participants of construction projects point of view are described in Table 1 .

Table 1. Table title. Table captions should always be positioned above the tables.

\begin{tabular}{ll}
\hline Example & Respondents in $\%$ \\
\hline Divided according to enterprise size & \\
Large enterprises & $4.24 \%$ \\
Medium sized enterprises & $27.06 \%$ \\
Small enterprises & $31.79 \%$ \\
Microenterprises & $32.94 \%$ \\
Divided according to participants of construction & \\
project & \\
Main contractors & $36.47 \%$ \\
Sub-contractors & $27.06 \%$ \\
Investors and developers & $14.12 \%$ \\
Designers & $22.35 \%$ \\
\hline
\end{tabular}

\subsection{Research steps and methodology}

First of all, it was set problem statement based on theoretical background. It was set research questions and hypotheses in this issue. Next step, it was data collection. All information about research sample and data collection process.

Next step, it was testing normality. The normality assumption needs to be considered for validation of data presented in the literature as it shows whether correct statistical tests have been used [26]. For this, it was used very common test called Shapiro-Wilk test to determine if the null hypothesis of normality is a reasonable assumption regarding the population distribution of a random sample. The desired significance level alpha was used 5\%. The desired hypotheses: research sample does have normal distribution (with unspecified mean and variance) or research sample does not have normal distribution. Computation of this test was done in Matlab. Research sample doesn't have normal distribution. Based on this result, it was chosen Mann-Whitney U test. All results of this test are shown in results chapter.

To confirm our hypotheses about mean ranks, the Mann-Whitney $U$ test was used. It is nonparametric alternative to t-test and it does not assume any assumptions related to the distribution of scores [27]. This test is used to compare two sample means that come from the same population, and used to test whether two sample means are equal or not. The desired significance level alpha was $5 \%$.

Calculation of the Mann-Whitney U:

$$
U=n_{1} n_{2}+\frac{n_{2}\left(n_{2}+1\right)}{2}-\sum_{i=n_{1}+1}^{n_{2}} R_{i}
$$

Where:

$U$ = Mann-Whitney U test

$n_{1}=$ sample size one 
$n_{2}=$ sample size two

$R_{i}=$ rank of the sample size

\section{Results}

\section{Research area - impact of enterprise information systems on cost in construction enterprises}

It's not easy verifiable that enterprise information system has a positive impact on business performance indicators. First of all, it's necessary to monitor the development of key indicators. This research was focused on cost in construction enterprises and revenues of construction enterprises in Slovakia. In the monitored period, these indicators were recorded in construction enterprises in Slovakia. This is necessary to say that, when implementing an enterprise information system, businesses themselves tracked these indicators and did not perform any other activity to measure the profitability of new innovations. In the first step, the cost of the enterprise were monitored, before and after the implementation of the enterprise information system.

So we used very common test called Shapiro-Wilk test to determine if the null hypothesis of normality is a reasonable assumption regarding the population distribution of a random sample. The desired significance level alpha was used 5\%. The desired hypotheses:

Research sample does have normal distribution (with unspecified mean and variance) or research sample does not have normal distribution.

Computation of this test was done in Matlab. We have tested differences between each measurement (Cost before implementing - Cost after implementing). These results were obtained:

Table 2. Results of research sample distribution

\begin{tabular}{lccc}
\hline & $\begin{array}{c}\text { Cost before } \\
\text { implementing }\end{array}$ & $\begin{array}{c}\text { Cost after } \\
\text { implementing }\end{array}$ & $\begin{array}{c}\text { Cost } \\
\text { Differences }\end{array}$ \\
\hline $\begin{array}{l}\text { Mean } \\
\text { Standard }\end{array}$ & 3.263636 & 2.454545 & 0.809091 \\
$\begin{array}{l}\text { Deviation } \\
\text { Number of } \\
\text { respondents }\end{array}$ & 0.659125 & 0.644473 & 0.697248 \\
Skewness & 110 & 110 & 110 \\
Kurtosis & -0.341614 & 0.486406 & 0.444224 \\
p value & -0.734193 & -0.058708 & 1.737712 \\
\hline
\end{tabular}

Research data were not normally distributed (see also the Figure 1). 


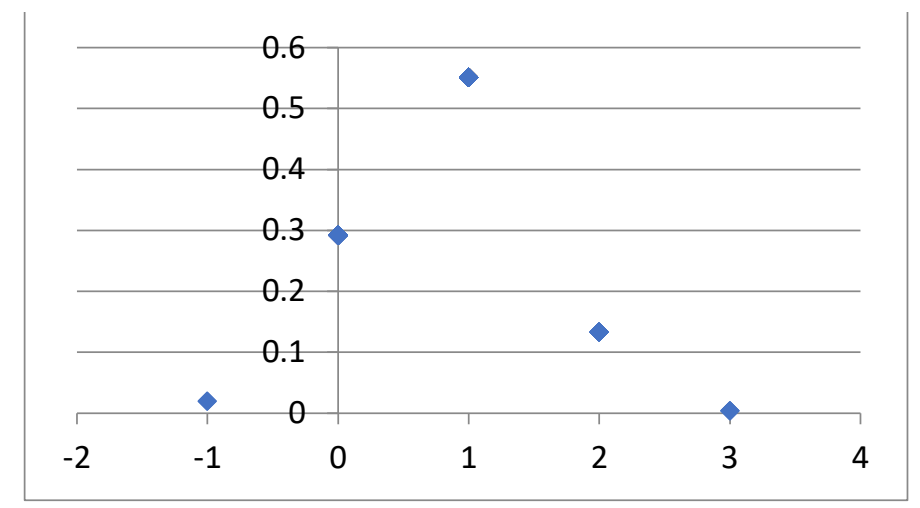

Fig. 1. The graph of distribution of costs differences

Subsequently, the Mann-Whitney test was used with these results. As we mentioned previously, the null and two-sided research hypotheses were stated as follows:

$\mathrm{H}_{0}$ : The mean ranks of two groups are equal.

$\mathrm{H}_{1}$ : The mean ranks of two groups are not equal (assume that mean of „,cost before enterprise information system implementing" > mean of cost after enterprise information system implementing ")

Table 3. Results of Mann-Whitney U test for cost

\begin{tabular}{lcc}
\hline & $\begin{array}{c}\text { Cost before } \\
\text { implementing }\end{array}$ & $\begin{array}{c}\text { Cost after } \\
\text { implementing }\end{array}$ \\
\hline Sum of ranks & 15620.5 & 8689.5 \\
Mean of ranks & 142 & 79 \\
Expected mean of ranks & 110.5 & 110.5 \\
U- value & 2584.5 & 9515.5 \\
Z-score & 7.34015 & \\
p value & $<.00001$ & \\
Expected U-value & 6050 & \\
Expected sum of ranks & 12155 & \\
\hline
\end{tabular}

$\mathrm{H}_{0}$ was rejected, It means of samples were not equal. In addition, mean of ranks were numerically compared so we could assume that really "Cost before implementing EIS" > „,costs after implementing EIS“. We were interested in linear correlation between our groups (samples) and it was computed in Excel. The correlation coefficient $r=0.428$ so we could talk about soft positive correlation.

Based on the results, it is not clear that the cost has been reduced due to the implementation of the enterprise information system. However, research results confirmed a slight correlation and clearly do not rebut the previous claim. Generally, results can be 
considered as a trend. Of course, it is possible to question whether the cost reduction was only due to the implementation and use of the enterprise information system. On the other hand, it has to be said that the research was counted and costs were cleared for other impacts.

\section{Research area - impact of enterprise information systems on revenues in construction enterprises}

Assumption that enterprise information system has a positive impact on revenues of construction enterprise must be verifying by some research steps. In other words, assumption that revenues after enterprise information system implementing are higher than revenues of construction enterprises before enterprise information system implementing. The same analysis was done.

Table 4. Results of research sample distribution

\begin{tabular}{lccc}
\hline & $\begin{array}{c}\text { Revenues } \\
\text { before } \\
\text { implementing }\end{array}$ & $\begin{array}{c}\text { Revenues after } \\
\text { implementing }\end{array}$ & $\begin{array}{c}\text { Revenues } \\
\text { Differences }\end{array}$ \\
\hline $\begin{array}{l}\text { Mean } \\
\text { Standard }\end{array}$ & 1.990909 & 2.863636 & -0.872727 \\
$\begin{array}{l}\text { Deviation } \\
\text { Number of }\end{array}$ & 0.723085 & 0.795368 & 0.576435 \\
respondents & 110 & 110 & 110 \\
Skewness & 0.458585 & 0.139053 & 0.582718 \\
Kurtosis & 0.236214 & 0.581687 & 1.513598 \\
$\mathrm{p}$ value & & & $<.000001$ \\
\hline
\end{tabular}

The hypothesis about normal distribution was rejected (see also Graph 2).

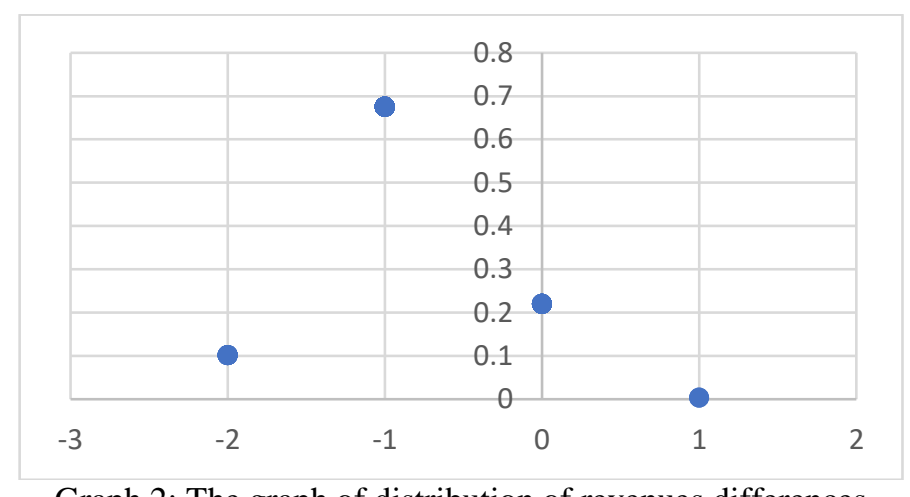

Graph 2: The graph of distribution of revenues differences

The equality of means was tested with Mann-Whitney U test.

$\mathrm{H}_{0}$ : The mean ranks of two groups are equal.

$\mathrm{H}_{1}$ : The mean ranks of two groups are not equal (assume that mean of ,revenues after enterprise information system implementing" $>$ mean of cost before revenues information system implementing ") 
Table 5. Results of Mann-Whitney U test for revenues

\begin{tabular}{lcc}
\hline & $\begin{array}{c}\text { Revenues before } \\
\text { implementing }\end{array}$ & $\begin{array}{c}\text { Revenues after } \\
\text { implementing }\end{array}$ \\
\hline Sum of ranks & 8749.5 & 15560.5 \\
Mean of ranks & 79.54 & 141.46 \\
Expected mean of ranks & 110.5 & 110.5 \\
U- value & 9455.5 & 2644.5 \\
Z-score & -7.21305 & \\
p value & $<.00001$ & \\
Expected U-value & 6050 & \\
Expected sum of ranks & 12155 & \\
\hline
\end{tabular}

$\mathrm{H}_{0}$ was rejected, it means of samples were not equal. In addition, mean of ranks were numerically compared so we could assume that really "Revenues before implementing" < „Revenues after implementing“. The correlation coefficient $r=0.716$ so we could talk about slightly strong positive correlation.

Generally, these results are clearer. The correlation coefficient shown on strong positive correlation. Revenues after enterprise information system are higher and test shown a significant impact. These results were more distinctive than cost results. Impact on revenues is higher.

\section{Conclusion}

The issue of enterprise information system impact on business performance is the current topic. It was set assumption that implementing of enterprise information system has impact on business performance indicators. In other words, selected indicators like cost and revenues are positively changed after enterprise information system implementing. Aim of research was set to verifying claims. Results of research are supported statistical test like Shapiro-Wilk test to determine the normality is a reasonable assumption regarding the population distribution of a random sample and Mann-Whitney $U$ test is nonparametric alternative to t-test and it does not assume any assumptions related to the distribution of scores. Based on these tests, it can be said follow research results. Enterprise information system implementing impact on cost and revenues on enterprises in construction industry in Slovakia. Both of correlation are positive. That means cost after implementing was lower than cost before implementing. The same positive impact was confirmed for revenues. It means that revenues after enterprise information system implementing were higher than before implementing. Based on research results, it seems to be very important use the enterprise information system in construction industry. For the following research, it can be interesting the tracking the profits of these enterprises. There may be a situation where revenues have risen. On the other hand, the question is whether the profit has also risen. Here is the scope for verifying that an enterprise information system has an impact on profit in construction enterprises. 


\section{Acknowledgements}

The paper presents a partial research results of project VEGA 1/0828/17 "Research and application of knowledge-based systems for modeling cost and economic parameters in Building Information Modeling".

„This work was supported by the Slovak Research and Development Agency under the contract no. APVV-17-0549“.

\section{References}

[1] Kolarić, S., Vukomanovoć, M.: Potential of BIM and ERP integration in contractor construction companies. Conference proceedengs: $13^{\text {th }}$ international conference Organization, technology and management in construction, Zagreb, pp. 669-673, ISBN 978-953-8168-21-5 (2017)

[2] Peraković, D., Periša, M., Sente, R.E., Bijelica, N., Brletić, L., Bucak, B., Ignjatić, A., Mišić, V., Papac, A., Vuletić, M., Zorić, P.: Information and communication system for informing users in traffic environment. 2nd EAI International Summit, Smart City 360, Bratislava, Slovakia, ISBN: 978 163190149-2 (2016)

[3] Radziszewska-Zielina, E.: Analysis of the Profitability of Investment in Renewable Energy Sources on the Example of A Semi-Detached House. E3S Web of Conferences - 1st International Conference on the Sustainable Energy and Environment Development, vol. 10, (2016)

[4] Mesároš, P., Mandičák, T., Mesárošová, A. \& Behún, M.: Developing managerial and digital competencies trough BIM technologies in construction industry, ICETA 2016 - 14th IEEE International Conference on Emerging eLearning Technologies and Applications, Proceedings, vol. 14, pp. 217-222, (2016)

[5] Kršák, B., Kyšel'a, K.: The use of social media and internet data-minig for the tourist industry. Journal of Tourism \& Hospitality, Vol. 5, pp. 1-3, ISSN 2167-0269, (2016)

[6] Čarnický, Š.: Manažérske informačné systémy podnikov. Bratislava: Ekonóm, ISBN 80-2251822-0, (2004)

[7] Čarnický, Š., Mesároš, P.: Informačné systémy podnikov. Bratislava: Ekonóm, p. 233, ISBN 97880-225-2676-0, (2009)

[8] David T. Bourgeois, Information Systems for Business and Beyond, Saylor Academy, (2014)

[9] Mihane Berisha-Namani.: The role of information systems in management decision making - an theoretical approach, Manager Journal, vol. 12, pp. 109-116, (2010)

[10] Haag, S. - Cummings, M. Essentials of Information Systems, McGraw-Hill, New York. (2006)

[11] Čarnický, Š.: Strategická úloha informačných systémov. Acta oeconomica Cassoviensia, Vol. 5, (2001)

[12] Kasemsap, K.: The role of information system within enterprise architecture and their impact on business performance - Global Business Expansion: Concepts, Methodologies, Tools, and Appl. , pp 1078-1102, (2018)

[13] Szilva, I., Caganova, D., Bawa, M., Pechanova, L., Hornakova, N.: Knowledge management perception in industrial enterprises within the CEE region, Lecture Notes of the Institute for Computer Sciences, Social-Informatics and Telecommunications Engineering, LNICST, 2nd EAI International Conference on ICT Infrastructures and Services for Smart Cities, IISSC 2017 and 2nd International Conference on Cloud, Networking for IoT systems, CN4IoT 2017, Vol. 189, pp. 66 $75,(2018)$ 
[14] Mesároš, P., Mandičák, T.: Impact of ICT on performance of construction companies in Slovakia, IOP Conference Series: Materials Science and Engineering : WMCAUS 2017. - Bristol : IOP Publishing, Vol. 24, pp. 1-9, ISSN 1757-8981, (2017)

[15] Turban, E. et al.: Information Technology for Management : Transforming Organizations in the Digital Ecomonomy, (2008)

[16] Balaban, N., Belić, K., Gudelj, M.: Business Process Performance Management: Theoretical and Methodological Approach and Implementation Management Information Systems, Vol. 6, pp. 003009, (2011)

[17] Otley, D.: Management control and performance management: whence and wither? The British Accounting Review, Vol. 35, pp. 309-326, (2003)

[18] Devis, B., Brabander, E.: ARIS Design Platform - Getting Started With BPM. Berlin: Springer, (2009)

[19] Eckerson, W.: Benchmark Guide: Interpreting Benchmark Scores Using TDWI's Maturity Model, (2007)

[20] Neely, A.: Business performance measurement - Theory and practice. Cambridge university press, ISBN $052180342 \mathrm{X}(2002)$

[21] Tripathi, K.K., Jha, K.N.: An Empirical Study on Performance Measurement Factors for Construction Organizations, KSCE Journal of Civil Engineering, Vol. 22, pp. 1052-1066, (2018)

[22] Robinson, H.S., et al.: Business performance measurement practices in construction engineering organisations. Measuring Business Excellence, Vol. 9, pp. 13 - 22, (2005)

[23] Mesároš, P., Mandičák, T.: Impact of information and communication technology on cost management in construction industry Empirical study, Wambeek : EuroScientia, 136 p., ISBN 97890-828093-2-9, (2017)

[24] Kokles, M. - Romanová, A.: Informačný vek. 2. vyd. Bratislava : Sprint, 2002. 305 p., ISBN 8089085-09-1, (2002)

[25] Mesároš, P., Mandičák, T.: Impact of ICT on performance of construction companies in Slovakia, IOP Conference Series: Materials Science and Engineering: WMCAUS 2017. - Bristol: IOP Publishing, Vol. 24, p. 1-9. - ISSN 1757-8981, (2017)

[26] Ghasemi, A., Zahedias, S.: Normality tests for statistical analysis: A guide for non-statisticians, Int. Journal Endocrinol Metab, Vol. 10, pp. 486-489, (2012)

[27] MacFarland T.W., Yates J.M.: Mann-Whitney U Test. Introduction to Nonparametric Statistics for the Biological Sciences Using R. Springer, (2016) 